Pegas, F.V. Proteção de biodiversidade via Ecoturismo: o uso de incentivos econômicos como ferramenta de conservação. Anais do VIII Congresso Nacional de Ecoturismo e do IV Encontro Interdisciplinar de Ecoturismo em Unidades de Conservação. Revista Brasileira de Ecoturismo, São Paulo, v.4, n.4, 2011, p. 500.

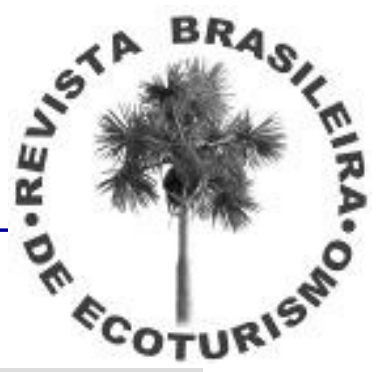

\title{
PROTEÇÃO DE BIODIVERSIDADE VIA ECOTURISMO: O USO DE INCENTIVOS ECONÔMICOS COMO FERRAMENTA DE CONSERVAÇÃO
}

\author{
Fernanda de Vasconcellos Pegas* \\ ${ }^{*}$ Griffith University - International Centre for Ecotourism Research \\ E-mail: f.pegas@griffith.edu.au
}

A premissa central do ecoturismo é gerar benefícios diretos para o meio ambiente e para as comunidades locais, como por exemplo fornecer alternativas de renda, melhorar a infra-estrutura local e gerar oportunidades de emprego. O pressuposto é que estes benefícios tornem-se incentivos para que os moradores destes comunidades apoiem a conservação ambiental via ecoturismo. Na prática, vários são os casos em que as metas sócio-econômicas, ambientais, ou ambas, não foram alcançadas. Por quase 30 anos, o Programa Brasileiro de Conservação das Tartarugas Marinhas (TAMAR) vem oferecendo incentivos econômicos (empregos e alternativas de renda) via ecoturismo como ferramenta para proteger as tartarugas marinhas e seus ninhos na comunidade de Praia do Forte, Bahia. O presente estudo avalia a relação entre estes benefícios econômicos e a conservação das tartarugas. Dados foram coletados durante nove meses de pesquisa etnográfica, entre 2006 e 2008, usando entrevistas semi-estruturadas com 77 moradores da Praia do Forte. Entre os entrevistados, 25 trabalhavam para o TAMAR e 15 são pescadores locais. Resultados demonstram um apoio geral por parte da comunidade em relação à protecao das tartarugas. Entre os entrevistados,74 (96\%) consideram o TAMAR uma organização que oferece empregos, alternativas de renda e oportunidades de educação para a comunidade. Setenta e dois entrevistados afirmaram ter uma perspetiva diferente sobre as tartarugas, sendo a influência econômica via ecoturismo na economia local um dos fatores mais citados pelos entrevistados. Apesar do reconhecimento e valorização econômica, a média salarial dos funcionários do TAMAR foi mais baixa do que a média relatada pelos entrevistados que trabalham como autônomos ou em outros estabelecimentos na vila. Fatores não econômicos, como o estabelecimento de um relacionamento positivo e laços de confiança com os fundadores do Projeto são fatores que influenciam a maneira pela qual vários entrevistados se identificam e valorizam o TAMAR. Quarenta e oito entrevistados disseram que as ameaças às tartarugas persistem apesar da tradição de caçar tartarugas e coletar ovos tenha diminuído significalmente desde 1982. Treze entrevistados sabiam de pelo menos um caso de caça entre 2007 e 2008, sendo os pescadores de lagosta e trabalhadores de construção, ambos não locais, citados como responsáveis por tal prática. A presença destes moradores na vila é associada com o intenso desenvolvimento da indústria do turismo na região. De fato, 51(66\%) entrevistados citaram o aumento do custo de vida, tráfico de drogas, violência, e prostituição na vila como problemas gerados pelo turismo. Para 72 (94\%) dos entrevistados, a qualidade de suas vidas irá deteriorar nos próximos cinco anos por causa dos impactos gerados pelo turismo na região. $O$ fato do ecoturismo ser implementado paralelo ao turismo de massa salienta a complexidade enfrentada por vários projetos de conservação. Sendo assim, apesar de ter o apoio da comunidade e ter atingido grande sucesso na diminuição da caça predatória das tartarugas na região, o desafio de criar e manter as condições que beneficiem a comunidade e o meio ambiente continuam.

Palavras-chave: Ecoturismo; Desenvolvimento Comunitário; Tartarugas Marinhas 